\title{
MOTIVASI, BIMBINGAN DAN PERHATIAN ORANG TUA SISWA DALAM PENDIDIKAN DI MTS. BAITURRAHIM KABAR KECAMATAN SAKRA LOMBOK TIMUR
}

\author{
Syahdan \\ STIT Palapa Nusantara \\ syahdan@stitpn.ac.id
}

\begin{abstract}
The purpose of this study is to find out or obtain information or a clear picture of the forms of roles performed by parents of students in helping the success of education, especially Islamic religious education in MTs. Baiturrabim Kabar 2019/2020 Academic Year. The benefits expected in this study can provide benefits for researchers, teachers, and parents of students to create conducive learning facilities, can provide information for parents of students to be able to create a good home environment for their children to pursue and practice the lessons learned. This study was designed in the form of a qualitative study by describing data relating to the variables in this study regarding parental participation in supporting the success of Islamic education in students in MTs. Baiturrabim Kabar. While the study population was all MTs students. NW Baiturrabim Kabar, amounting to 52 students from grade VII to class IX. The instruments used to obtain data are questionnaires / questionnaires, and interviews. The results obtained are the participation of parents in Islamic religious education of their students classified as moderate. This form of parental participation consists in providing motivation, guidance, and attention. Motivation has a very important role in motivating, building the personality and intellect of students to better the future of their children based on the demands of the Islamic religion. The most visible guidance for students is giving advice, giving good ways to get along, speaking well, giving a set of dreams, giving sanctions if guilty. While participation in parents in giving attention to their students to pay attention to all the needs that support learning for their students both within the family and in the wider community.
\end{abstract}

Keywords: motivation, guidance, attention, Islamic religious education

\begin{abstract}
Abstrak : Tujuan penelitian ini adalah untuk mengetahui atau memperoleh informasi atau gambaran yang jelas bagaimana bentuk-bentuk peran yang dilakukan oleh orang tua peserta didik dalam membantu keberhasilan pendidikan khususnya pendidikan agama Islam di MTs. Baiturrahim Kabar Tahun Pelajaran 2019/2020. Adapun manfaat yang diharapkan dalam penelitian ini dapat memberikan manfaat bagi peneliti, guru, dan orang tua siswa guna menciptakan sarana belajar kondusif, dapat memberikan informasi bagi orang tua siswa untuk dapat menciptakan lingkungan rumah yang baik bagi anaknya dalam menekuni dan mengamalkan pelajaran yang telah diperoleh. Penelitian ini didesain dalam bentuk penelitian kualitatif dengan mendeskripsikan data yang berkaitan dengan variabel-variabel pada penelitian ini
\end{abstract}

Islamika : Jurnal Keislaman dan Ilmu Pendidikan

Volume 1, Nomor 2, Juli 2019; 181-203

https:// ejournal.stitpn.ac.id/index.php/islamika 
mengenai partisipasi orang tua dalam menunjang keberhasilan pendidikan Islam pada anak didik di MTs. Baiturrahim Kabar. Sedangkan populasi penelitian ini adalah seluruh siswa MTs. NW Baiturrahim Kabar yang berjumlah 52 siswa dari kelas VII sampai dengan kelas IX. Adapun instrumen yang digunakan untuk memperoleh data adalah angket/kuesioner, dan wawancara. Hasil yang didapatkan adalah Partisipasi orang tua terhadap pendidikan agama Islam anak didiknya tergolong sedang. Bentuk partisipasi orang tua ini terdiri atas pemberian motivasi, bimbingan, dan perhatian. Pemberian motivasi memiliki peran yang sangat penting dalam memotivasi, membangun kepribadian dan intelektualitas siswa untuk menyongsong masa depan anaknya yang lebih baik berdasarkan tuntutan agama Islam. Pemberian bimbingan kepada anak didiknya yang paling nampak adalah memberikan nasihat, memberikan cara bergaul yang baik, bertutur kata yang baik, memberikan semangat dalam meraih cita-cita, memberikan sanksi jika bersalah. Sedangkan partisipasi dalam orang tua dalam memberikan perhatian anak didiknya untuk memperhatikan segala kebutuhan yang menunjang pembelajaran pada anak didiknya baik di lingkungan keluarga maupun di lingkungan masyarakat luas.

Kata Kunci: Motivasi, Bimbingan, Perhatian, Pendidikan Agama Islam

\section{PENDAHULUAN}

Pendidikan merupakan suatu wadah yang dapat membentuk jiwa dan kepribadian pada setiap manusia sejak lahir yang diawali dari pendidikan di dalam keluarga, lingkungan, dan sekolah. Dalam pembentukan mental, emosi, dan adaptasi dengan lingkungannya tidak terlepas dari peran orang tua dalam mengarahkan dan membentuk karakteristik anak di lingkungan keluarga.

Tirtararaharja \& La Sulo ${ }^{1}$ menjelaskan bahwa lingkungan keluarga sungguhsungguh merupakan pusat pendidikan yang penting dan menentukan, karena itu tugas pendidikan adalah mencari cara, membantu para ibu dalam tiap keluarga agar dapat mendidik anak-anaknya secara optimal.

Dalam mendidik anak tidak terlepas dari kesulitan-kesulitan baik yang dialami oleh orang tua maupun oleh guru di sekolah. Demikian pula halnya bagi anak didik juga banyak sekali faktor-faktor yang menghambat kelancaran proses belajarnya sehingga sangat sulit memerlukan pemecahan dan pemikiran yang serius serta penelitian yang mendasar guna penyelesaian masalah tersebut. Oleh karena itu orang tua harus berpartisipasi di dalam mendidik anak-anaknya agar tumbuh menjadi

${ }^{1}$ Umar Tirtaraharja dan S.L. La Sulo, Pengantar Pendidikan. Edisi Revisi. Jakarta : Rineka Cipta, 2005 hal. 170. 
manusia yang beriman dan bertaqwa kepada Allah SWT. serta dapat pula berkembang menjadi manusia dewasa, baik dewasa jasmani ataupun dewasa rohaninya.

Kaitannya dalam semua ini sangat penting sekali kemampuan dan kepekaan orang tua dalam menunjang keberhasilan pendidikan, khususnya pada madrasah atau sekolah. Salah satu kemampuan dasar yang harus menjadi partisipasi orang tua dalam kaitannya dengan masalah di atas adalah kemampuan merencanakan dan melaksanakan proses belajar mengajar ${ }^{2}$.

Gerakan kependidikan yang mempunyai landasan ideal dan operasional yang kokoh berdasarkan nilai-nilai yang pasti dan antisipatif kepada kemajuan hidupa masa yang mendatang adalah hanya madrasah yang mampu berperan inovatif, maksudnya pendidikan berorientasi kepada kehidupan manusia di masa datang di mana ruang lingkup menjalankan aspirasi rising (tuntutan naluri) manusia dibarengi dengan nilai Islam yang bersifat mengendalikan nafsu-nafsu destruktif (rintangan) tata nilai Islam itu tergambar pada kategori nilai yang pokatistik dari yang wajib dikerjakan sampai dengan yang terlarang dikerjakan yang di antara kedua ujungnya terdapat nilai lentur. Untuk merealisasikan tujuan tersebut maka pendidikan agama harus dilaksanakan di lembaga-lembaga pendidikan sesuai dengan yang berlaku dan mendapat perhatian yang mendalam dari seluruh umat Islam. Dalam pelaksanaan pendidikan Islam sangat memerlukan penyempurnaan teknis (orang tua) baik dari segi mengajar, alat pengajar.

Orang tua adalah tumpuan dan pengayom seorang anak, kemajuan dan kemunduran, keberhasilan dan kegagalan yang dialami seorang anak adalah cermin dari keadaan orang tua yang mengasuh dan membesarkannya. Karena itu sebagai orang tua yang sadar akan pentingnya pendidikan diharapkan dapat memberikan dukungan dan motivasi kepada anaknya supaya sukses dan berhasil dalam proses pembelajaran. Karena keberhasilan seorang anak berarti juga keberhasilan orang tua disebabkan anak itu sendiri merupakan cermin dari orang tuanya. Akan tetapi keberhasilan seorang anak akan didapat dan diperoleh bila ditunjang dengan biaya. Seorang anak masih banyak rendah pengetahuannya dan kurang berhasil karena kesulitan dan kekurangan biaya atau dana.

${ }^{2}$ Slameto, 2010. Belajar dan faktor-faktor yang Mempengarubinya. Jakarta : Rineka Cipta. Hal. 9. 
MTs. Baiturrahim adalah satu satuan pendidikan yang bernaung di bawah yayasan Baiturrahim. Keberadaannya masih eksis sampai dengan saat ini walau dari tahun ke tahun sejak berdirinya tahun 2003 dan meluluskan lulusan perdana tahun 2005 belum pernah meluluskan siswa lebih dari 30 orang bahkan beberapa tahun pernah meluluskan siswa antara 5 sampai dengan 9 orang dan prestasi rata-rata cukup baik $^{3}$. Hal tersebut diduga bahwa pemicunya kurangnya partisipasi orang tua siswa dalam memberikan motivasi atau bimbingan kepada anak-anaknya di samping keterbatasan madrasah secara finansial dalam meningkatkan kualitas maupun kuantitas.

Namun 3 tahun terakhir berdasarkan pengamatan penulis serta laporanlaporan tertulis dari dokumen-dokumen madrasah, MTs. Baiturrahim Kabar mengalami dinamika, baik sisi kualitas/prestasi maupun kuantitas jumlah siswa. Hal tersebut berkat upaya-upaya yang dilakukan madrasah, dan tak terkecuali adanya partisipasi orang tua siswa dalam memberikan motivasi, bimbingan dan lain sebagainya kepada anak-anak mereka.

Berdasarkan pada latar belakang di atas, permasalahan tersebut dapat dirumuskan dalam sebuah pertanyaan yaitu; Bagaimana Partisipasi orang tua dalam menunjang keberhasilan pendidikan Islam peserta didik di MTs Baiturrahim Kabar. Tujuan dari penelitian ini adalah untuk memperoleh gambaran yang jelas bagaimana bentuk-bentuk peran yang dilakukan oleh orang tua peserta didik dalam membantu keberhasilan pendidikan khususnya pendidikan agama Islam. Adapun manfaat yang diharapkan dalam penelitian ini dapat memberikan manfaat bagi peneliti, guru, dan orang tua siswa guna menciptakan sarana belajar kondusif, dapat memberikan informasi bagi orang tua siswa untuk dapat menciptakan lingkungan rumah yang baik bagi anaknya dalam menekuni dan mengamalkan pelajaran yang telah diperoleh.

\section{KAJIAN PUSTAKA}

\section{Tangggung Jawab Orang Tua terhadap Keberhasilan Pendidikan Anak}

Orang tua memiliki peranan yang sangat penting dalam memberikan arahan dan bimbingan dalam menunjang keberhasilan pendidikan anak mereka

\footnotetext{
${ }^{3}$ Wawancara dengan wakil kepala madrasah urusan kurikulum tanggal 1 Juli 2019
} 
khususnya dalam pendidikan agama. Para pemimpin Islam di dalamnya terdapat kaum muslimin yang tentu saja menghendaki agar setiap anak menjadi orang yang taat dan patuh dalam menjalankan perintah agamanya baik di lingkungan keluarga, teman sepermainan, teman sekelas, dan siswa di dalam sekolah.

Dengan demikian pada lingkungan keluarga, para pemimpin, dan masyarakat memiliki tanggung jawab terhadap pendidikan anak di dalam bimbingan dan memberikan arahan yang dapat bermanfaat bagi anak didik. Pada hakekatnya pendidikan merupakan tanggung jawab para pemimpin dan masyarakat dalam membina moral, etika, sikap, kepribadian, dan rasa tanggung jawab pada diri sendiri baik dalam individu amupun berkelompok, hal tersebut dikemukakan oleh Zakiyah Darajat ${ }^{4}$ :

"Di antara ulama-ulama mutakhir yang telah menyentuh persoalan tnggung jawab adalah Abbas mahmud Al-Akkad yang menganggap rasa tanggung jawab sebagai salah satu ciri pokok bagi manusia pada pengertian Al-Qur'an dan Islam, sehingga dapat ditafsirkan manusia sebagai makhluk yang bertanggung jawab".

Senada dengan pernyataan tersebut di atas Arifin dan Aminuddin Rasyad ${ }^{5}$ mengemukakan bahwa tanggung jawab yang perlu didasarkan dan dibina oleh orang tua terhadap anak antara lain : a). Memelihara dan membesarkannya, tanggung jawab ini merupakan dorongan alami untuk dilaksanakan, karena anak memerlukan makan, minum dan perawatan, agar ia dapat hidup secara berkelanjutan. b). Melindungi dan menjamin kesehatannya, baik secara jasmaniah maupun rohaniah dari berbagai gangguan penyakit atau bahaya lingkungan yang dapat membahayakan dirinya. c). Mendidiknya dengan berbagai ilmu pengetahuan dan keterampilan yang berguna bagi kehidupannya kelak sehingga bila ia telah dewasa mampu berdiri sendiri dan membantu orang lain (bablum minannas) dan melaksanakan kekhalifahannya. Dan d). Membahagiakan anak

${ }^{4}$ Darajat Zakiyah., dkk, Ilmu Jiwa Agama, Edisi Revisi. Jakarta : Bulan Bintang, 2002, hal. 62

${ }^{5}$ Arifin H.M. dan Aminuddin Rasyad, Dasar-dasar Pendidikan Edisi Revisi, Direktorat Jenderal Pembinaan Kelembagaan Agma Islam, 2003, hal 263. 
untuk dunia dan akhirat dengan memberinya pendidikan agama sesuai dengan ketentuan Allah sebagai tujuan akhir hidup muslim. Tanggung jawab ini dikategorikan juga kepada tanggung jawab kepada Allah.

Tanggung jawab orang tua terhadap pelaksanaan pendidikan Islam bukanlah merupakan gejala yang relatif baru, di mana masyarakat yang merupakan kelompok manusia, juga menyadari adanya tanggung jawab tersebut setelah mereka menjadi anggota masyarakat, adanya penderitaan yang sama, ingin mencapai tujuan bersama, untuk mempertahankan diri dari berbagai hambatan hidup. Sebab itu makin tinggi keperluan/kebutuhan dari orang tua, makin tinggi pula kewajiban tanggung jawab terhadap benda-benda, dari bentuk yang sangat sederhana seperti rasa simpati, mengingat kepada penyampaian pendapat, baik bentuk terigan, protes maupun demontrasi sampai kepada bentuk partisipasi, dalam tingkat pengambilan keputusan, perencanaan maupun dalam pelaksanaan dari pendidikan Islam tersebut. Oleh karena itu partisipasi orang tua sangat diperlukan dalam menunjang keberhasilan pendidikan. Adapun bentuk-bentuk motivasi orang tua antara lain:

\section{a. Motivasi}

Kata "motif" diartikan sebagai daya upaya yang mendorong seseorang untuk melakukan sesuatu. Motif dapat dikatakan sebagai daya penggerak dari dalam diri dan di dalam subjek untuk melakukan aktivitas-aktivitas tertentu demi mencapai suatu tujuan. Sedangkan motivasi diartikan sebagai penggerak yang telah menjadi aktif. Motivasi dapat juga dikatakan sebagai rangkaian usaha untuk menyediakan kondisi-kondisi tertentu, sehingga seseorang mau dan ingin melakukan sesuatu.

Dimyati (dalam Sumarni) ${ }^{6}$ menjelaskan bahwa motivasi belajar merupakan kekuatan mental yang menjadi penggerak belajar. Kekuatan mental yang berupa keinginan, perhatian, kemauan atau cita-cita. Dalam motivasi terkandung adanya

\footnotetext{
${ }^{6}$ Sumarni, Meningkatkean Motivasi Belajar Matematika Melalui Metode Pemberian Kuis di Akbir Pembelajaran Disertai dengan Umpan Balik pada Siswa Kelas XI IP $A_{6} S M A$ Negeri 1 Sungguminasa Makasar, Skripsi. Makassar : Universitas Negeri Makassar Jurusan Matematika Fakultas matematika dan Ilmu Pengetahuan Alam, 2007, hal. 11.
} 
keinginan yang mengaktifkan, menggerakkan, menyalurkan, dan mengarahkan sikap dan perilaku individu belajar.

Selanjutnya ia juga menjelaskan bahwa "dalam kegiatan belajar, motivasi dapat dikatakan sebagai keseluruhan daya penggerak psikis dalam diri siswa yang menimbulkan kegiatan belajar, menjamin kelangsungan belajar itu demi mencapai satu tujuan.

\section{b. Bimbingan}

Bimbingan adalah bantuan yang diberikan kepada individu (peserta didik) agar dengan potensi yang dimiliki mampu mengembangkan diri secara optimal dengan jalan memahami diri, memahami lingkungan, mengatasi hambatan guna menentukan rencana masa depan yang lebih baik. Hal senada juga dikemukakan oleh Prayitno dan Erman Amti, Bimbingan adalah proses pemberian bantuan yang dilakukan oleh orang yang ahli kepada seseorang atau beberapa orang individu, baik anak-anak, remaja, atau orang dewasa; agar orang yang dibimbing dapat mengembangkan kemampuan dirinya sendiri dan mandiri dengan memanfaatkan kekuatan individu dan sarana yang ada dan dapat dikembangkan berdasarkan norma-norma yang berlaku ${ }^{7}$

Dari pendapat para ahli di atas, dapat disimpulkan bahwa bimbingan merupakan bantuan yang dilakukan oleh orang yang ahli kepada seseorang atau beberapa orang individu, baik anak-anak, remaja, atau orang dewasa; agar orang yang dibimbing dapat mengembangkan kemampuan dirinya sendiri dan mandiri dengan memanfaatkan kekuatan individu dan mengembangkan diri secara optimal dengan jalan memahami diri, memahami lingkungan, mengatasi hambatan guna menentukan rencana masa depan yang lebih baik.

\section{c. Perhatian}

Djamarah ${ }^{8}$ menjelaskan bahwa "perhatian" adalah keaktifan jiwa yang diarahkan kepada sesuatu objek baik di dalam maupun di luar dirinya. Perhatian seseorang yang tertuju pada suatu objek sebenarnya dimulai dengan adanya minat

\footnotetext{
${ }^{7}$ Abu Ahmadi dalam http://belajarpsikologi.com/Media-belajar-ilmu-psikologi-dan-bimbingankonseling/ Posted by' Admin on December 31, 2009 diakses 15 Januari 2013

${ }^{8}$ Djamarah, Saiful Bahri, Pendidik dan Anak Didik Dalam Interaksi Edukatif Suatu Pendekatan Teoretis Psikologis. Jakarta : Rineka Cipta, 2010, hal. 335.
} 
terhadap objek tersebut. Apa yang menarik minat dapat menyebabkan lahirnya perhatian dan apa yang menjadi perhatian terhadap suatu objek tertentu selalu saja disertai dengan minat. Oleh karena itu sangat logis jika dikatakan bahwa minat adalah alat motivasi. Minat berfungsi meneguhkan perhatian.

Perhatian merupakan keaktifan jiwa yang dipertinggi, jiwa semata-mata tertuju kepada suatu obyek ataupun sekumpulan obyek. Untuk dapat menjamin hasil yang baik, maka peserta didik harus dihadapkan pada obyek-obyek yang dapat menarik perhatian peserta didik, jika tidak, maka perhatian peserta didik tidak akan terarah atau fokus pada obyek yang sedang dipelajarinya.

\section{Materi Pendidikan Agama Islam}

Pendidikan Agama Islam di MTs. terdiri atas empat mata pelajaran, yaitu: Al-Qur'an-Hadis, Akidah-Akhlak, Fikih, dan Sejarah Kebudayaan Islam. Masingmasing mata pelajaran tersebut pada dasarnya saling terkait, isi mengisi dan melengkapi. Al-Qur'an-Hadis merupakan sumber utama ajaran Islam, dalam arti ia merupakan sumber akidah-akhlak, syari'ah/fikih (ibadah, muamalah), sehingga kajiannya berada di setiap unsur tersebut. Akidah (usuluddin) atau keimanan merupakan akar atau pokok agama. Syariah/fikih (ibadah, muamalah) dan akhlak bertitik tolak dari akidah, yakni sebagai manifestasi dan konsekuensi dari akidah (keimanan dan keyakinan hidup). Syari'ah/fikih merupakan sistem norma (aturan) yang mengatur hubungan manusia dengan Allah, sesama manusia dan dengan makhluk lainnya. Akhlak merupakan aspek sikap hidup atau kepribadian hidup manusia, dalam arti bagaimana sistem norma yang mengatur hubungan manusia dengan Allah (ibadah dalam arti khas) dan hubungan manusia dengan manusia dan lainnya (muamalah) itu menjadi sikap hidup dan kepribadian hidup manusia dalam menjalankan sistem kehidupannya (politik, ekonomi, sosial, pendidikan, kekeluargaan, kebudayaan/seni, iptek, olahraga/kesehatan, dan lain-lain) yang dilandasi oleh akidah yang kokoh. Sejarah Kebudayaan Islam merupakan perkembangan perjalanan hidup manusia muslim dari masa ke masa dalam usaha bersyariah (beribadah dan bermuamalah) dan berakhlak serta dalam mengembangkan sistem kehidupannya yang dilandasi oleh akidah. 
Pendidikan Agama Islam (PAI) di MTs. yang terdiri atas empat mata pelajaran tersebut memiliki karakteristik sendiri-sendiri. Al-Qur'an-Hadits, menekankan pada kemampuan baca tulis yang baik dan benar, memahami makna secara tekstual dan kontekstual, serta mengamalkan kandungannya dalam kehidupan sehari-hari. Aspek akidah menekankan pada kemampuan memahami dan mempertahankan keyakinan/keimanan yang benar serta menghayati dan mengamalkan nilai-nilai al-asma' al-husna. Aspek Akhlak menekankan pada pembiasaan untuk melaksanakan akhlak terpuji dan menjauhi akhlak tercela dalam kehidupan sehari-hari. Aspek fikih menekankan pada kemampuan cara melaksanakan ibadah dan muamalah yang benar dan baik. Aspek sejarah kebudayaan Islam menekankan pada kemampuan mengambil ibrah dari peristiwaperistiwa bersejarah (Islam), meneladani tokoh-tokoh berprestasi, dan mengaitkannya dengan fenomena sosial, budaya, politik, ekonomi, iptek dan seni, dan lain-lain untuk mengembangkan kebudayaan dan peradaban Islam.

\section{METODE PENELITIAN}

Desain penelitian ini menggunakan deskriptif kualitatif. Penelitian deskriptif adalah penelitian yang tidak membuat perbandingan variabel pada sampel lain tetapi mencari hubungan variabel yang satu dengan variabel yang lainnya. Penelitian ini didesain dalam bentuk penelitian kualitatif dengan mendeskripsikan data yang berkaitan dengan variabel-variabel pada penelitian ini mengenai partisipasi orang tua dalam menunjang keberhasilan pendidikan Islam pada anak didik di MTs. Baiturrahim Kabar.

Berdasarkan kondisi siswa yang ada dengan jumlah siswa kurang dari 100 orang, maka penelitian ini tidak menggunakan sampel. Jadi populasi penelitian ini adalah seluruh siswa MTs. NW Baiturrahim Kabar yang berjumlah 65 siswa dari kelas VII sampai dengan kelas IX.

Adapun instrumen yang digunakan untuk memperoleh data adalah angket/kuesioner, dan wawancara. Angket/kuesioner ini berisikan kumpulan butir pertanyaan atau pernyataan yang dijawab oleh siswa dengan jumlah pertanyaan/pernyataan 28 butir soal. Butir-butir pertanyaan/pernyataan ini mengenai bentuk partisipasi orang tua di antaranya mengenai motivasi, bimbingan, dan 
perhatian kepada anak dalam belajar pada umumnya dan belajar agama Islam pada khususnya.

Selanjutnya dalam hal ini juga digunakan wawancara. Wawancara yang dimaksud adalah melakukan tanya jawab dengan guru (yang mengajarkan PAI) atau kepala madrasah yang berkaitan dengan topik permasalahan yakni bentuk-bentuk permasalahan yang dihadapi oleh guru atau kepala madrasah dalam meningkatkan mutu pendidikan agama Islam di MTs. Baiturrahim Kabar.

Dalam menganalisis data kualitatif Bogdan \& Biklen dalam Lexy J. Moleong9 menyatakan bahwa "analisis data adalah upaya yang dilakukan dengan cara bekerja dengan data, mengorganisasikan data, memilah-milahnya menjadi satuan yang dapat dikelola...". Berdasarkan pendapat tersebut, maka teknik yang digunakan untuk menganalisis data pada penelitian ini adalah: 1). Mengumpulkan hasil jawaban angket/kuesioner. 2). Menganalisis jawaban siswa sesuai dengan butir-butir pertanyaan/pernyataan pada soal angket/kuesioner. 3). Mengumpulkan data hasil wawancara. 4). Melihat nilai hasil belajar PAI untuk dipadukan dengan jawaban siswa. 5). Menarik kesimpulan dari hasil analisis hasil jawaban angket/kuesioner dan nilai hasil belajar PAI, serta disesauaikan dengan hasil wawancara.

\section{HASIL DAN PEMBAHASAN}

\section{Hasil Penelitian}

Berdasarkan data yang telah dikumpulkan mengenai bentuk partisipasi orang tua dalam menunjang keberhasilan pendidikan Islam anak didiknya di MTs Baiturrahim Kabar yang tertuang dalam butir pertanyaan yang dijawab oleh siswa yang ada pada sampel penelitian. Isi butir pertanyaan ini berisi tentang motivasi, bimbingan, dan perhatian orang tua terhadap anak didiknya.

Partisipasi orang tua dalam memberikan motivasi kepada anak didik tertuang dalam butir pertanyaan pada angket/kuesioner yang hanya dijawab oleh anak didik pada sampel penelitian. Jumlah butir pertanyaan angket yang berkaitan dengan motivasi orang tua ini berjumlah 12 butir pertanyaan. Hal ini menandakan jumlah orang tua memberikan motivasi kepada anak didiknya. Sedangkan tingkat persentase

${ }^{9}$ Moleong, Leksi J. Metodologi Penelitian Kualitatif, Bandung : Remaja Rosda Karya, 2010, hal. 86 
partisipasi orang tua dilakukan berdasarkan persentase masing-masing pilihan butir pertanyaan angket/kuesioner yang dijawab oleh anak didik.

Partisipasi orang tua dalam memberikan bimbingan kepada anak didik tertuang dalam butir pertanyaan pada angket/kuesioner yang hanya dijawab oleh anak didik pada sampel penelitian. Jumlah butir pertanyaan angket yang berkaitan dengan bimbingan orang tua ini berjumlah 7 butir pertanyaan. Hal ini menandakan jumlah orang tua memberikan bimbingan kepada anak didiknya. Sedangkan tingkat persentase partisipasi orang tua dilakukan berdasarkan persentase masing-masing pilihan butir pertanyaan angket/kuesioner yang dijawab oleh anak didik.

Partisipasi orang tua dalam memberikan perhatian kepada anak didiknya tertuang dalam butir pertanyaan pada angket/kuesioner yang hanya dijawab oleh anak didik pada sampel penelitian. Jumlah butir pertanyaan angket yang berkaitan dengan bimbingan orang tua ini berjumlah 9 butir pertanyaan. Hal ini menandakan jumlah orang tua memberikan perhatian kepada anak didiknya. Sedangkan tingkat persentase partisipasi orang tua dilakukan berdasarkan persentase masing-masing pilihan butir pertanyaan angket/kuesioner yang dijawab oleh anak didik.

Berdasarkan hasil verifikasi data pada masing-masing item butir (partisipasi orang tua memberikan motivasi, bimbingan dan perhatian) di atas, maka partisipasi orang tua dalam memotivasi, memberikan bimbingan, dan perhatian berkategori sedang. Sehingga secara keseluruhan partisipasi orang tua terhadap pendidikan agama Islam terhadap anak didiknya adalah berkategori sedang.

\section{PEMBAHASAN}

\section{a. Partisipasi Orang Tua}

Partisipasi orang tua dalam mendidik anaknya tidak terlepas dari peran serta orang tua dalam memberikan motivasi, bimbingan, dan perhatian dalam membangun mental, kepribadian, tingkah laku/akhlak mulia, etika bergaul, dan lain sebagainya. Orang tua merupakan guru pertama dalam mendidik anak. Oleh karena itu, orang tua memiliki peranan yang sangat penting dan memiliki tanggung jawab yang besar terhadap pendidikan anak-anaknya. Hal ini sesuai dengan firman Allah : 


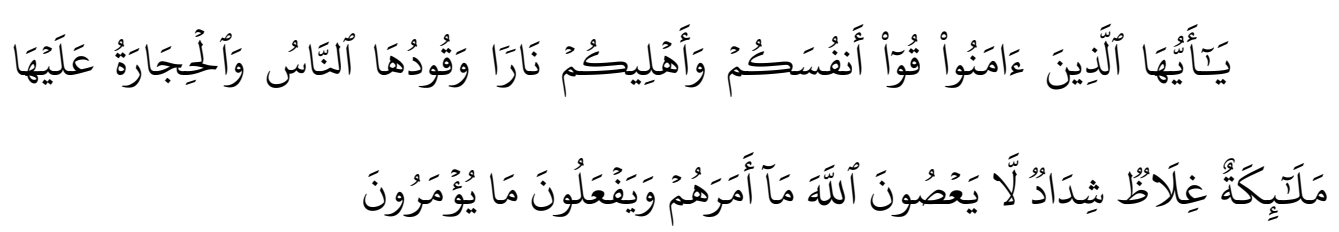

Artinya : Hai orang-orang yang beriman, peliharalah dirimu dan keluargamu dari api neraka yang bahan bakarnya adalah manusia dan batu; penjaganya malaikat-malaikat yang kasar, keras, dan tidak mendurhakai Allah terhadap apa yang diperintahkan-Nya kepada mereka dan selalu mengerjakan apa yang diperintahkan. ${ }^{10}$

Sehubungan dengan hasil perolehan data penelitian di atas, maka akan dibahas beberapa hal yang berkaitan dengan partisipasi orang tua dalam mendidik anaknya yakni partisipasi dalam memberikan motivasi, bimbingan dan perhatian.

\section{b. Partisipasi dalam Memberikan Motivasi}

Di antara butir pertanyaan yang berkaitan dengan pemberian motivasi yaitu; (1) memotivasi untuk rajin belajar berkategori sedang; (2) memberikan penghargaan dalam meraih prestasi berkategori tinggi; (3) memerintahan untuk mengaji di musholla/masjid berkategori tinggi; (4) mempelajari ilmu tajwid disaat mengaji berkategori tinggi; (5) membimbing dan mengajar anaknya di rumah berkategori sedang; (6) membimbing dan mengajar anaknya tentang cara-cara membaca al-Qur'an yang baik berkategori sedang; (7) membimbing dan mengajar anaknya tentang isi dan kandungan al-Qur'an berkategori sedang; (8) membimbing dan mengajar anaknya tentang ilmu-ilmu fiqih berkategori sedang; (9) membimbing dan mengajar anaknya tentang cara-cara berperilaku atau berakhlak yang baik berkategori sedang, (10) membimbing dan mengajar anaknya tentang kisah-kisah nabi dan rasul berkategori sedang; (11) membimbing dan mengajar anaknya tentang kisah-kisah nabi Muhammad SAW sebagai suri tauladan yang dapat ditiru dan diikuti dengan baik berkategori sedang; dan (12) orang tua memberikan suri tauladan yang baik yang patut diikuti berkategori tinggi.

10 QS. Attahrim ayat 6 
Di antara partisipasi dalam memberikan motivasi yang berhubungan dengan rajin belajar untuk meraih prestasi adalah butir 1 dan butir 2 butir soal angket/kuesioner. Pada butir 1 berhubungan dengan rajin belajar berkategori tinggi ini memberikan gambaran bahwa kesadaran orang tua dalam mendidik anaknya cukup signifikan. Hasil ini mengindikasikan bahwa rajin belajar atau menuntut ilmu merupakan wadah yang terpenting dan harus dilakukan karena menuntut ilmu hukumnya fardlu a'in sesuai dengan Hadits Rasulullah SAW:

اطلبو العلم من المهد الى اللحد

Artinya : tuntutlab ilmu dari sejak labir hingga ke liang lahat.

Orang yang rajin belajar adalah orang yang memiliki ilmu pengetahuan yang luas, karena ilmu pengetahuan dapat mengetahui cakrawala dunia dari kegelapan menuju ke kondisi dunia yang serba canggih dan modern seperti sekarang ini.

Dorongan orang tua untuk rajin belajar yang kuat, nantinya diharapkan bagi anaknya menjadi anak yang berguna bagi nusa dan bangsa yang berakhlakul karimah sesuai dengan tuntunan Rasululluh SAW, dan memiliki kepribadian luhur demi kemajuan dan kemaslahatan umat Islam pada khususnya dan umat pada umumnya.

Sementara yang berhubungan dengan pencapaian prestasi adalah butir 2 berkategori sedang. Hal ini mengindikasikan bahwa tingkat dorongan orang tua dalam memacu untuk berprestasi tergolong sedang.

Pemberian sugesti/dorongan orang tua untuk memacu dalam meraih prestasi belajar masih rendah, karena pada hakekatnya dorongan orang tua sangat diperlukan oleh anak didik untuk memacu diri dalam berprestasi. Pemberian hadiah diperbolehkan asalkan tidak bertentangan dengan ajaran agama dan tidak berlebihan.

Pemberian hadiah untuk berprestasi kepada anak akan memacu anak untuk bersaing secara kompetitif dan dapat memupuk semangat untuk berkarya secara displin, jujur, bertanggung jawab, mandiri, dan tidak malas. Perbuatan orang tua seperti ini dapat mencerminkan pendidikan berkarakter yang sedang digalakkan oleh pemerintah dengan tujuan agar anak didik menjadi anak yang berakhlak mulia dan berbudi pekerti yang luhur serta bermartabat. 
Partisipasi orang tua terhadap anak didiknya yang sehubungan dengan tuntutan untuk belajar tentang ilmu-ilmu agama baik di dalam rumah maupun di luar rumah. Di antara pembelajaran yang dilaksanakan di luar rumah adalah menyuruh anaknya untuk mengaji di musholla/masjid yang berkategori tinggi (pertanyaan butir 3). Demikian juga dorongan orang untuk belajar ilmu tajwid di saat mengaji di musholla/masjid juga berkategori tinggi (pertanyaan butir 4). Dalam mempelajari ilmu agama khususnya dalam mempelajari cara-cara membaca al-Qur'an beserta kajian bacaan maharijul huruf (ilmu tajwid) mendapat dorongan dan antusias yang kuat dari kalangan orang tua karena para orang tua menganggap bahwa belajar membaca dan ilmu tajwidnya sebagai tahap awal untuk mempelajari ilmu-ilmu agama lainnya, dan dirasa sangat penting dilakukan oleh anak didiknya.

Pembelajaran yang dilaksanakan di dalam rumah adalah sebagai berikut; (a) pada butir 5 mengenai pengajaran tentang pelajaran agama Islam secara umum berkategori sedang; (b) pada butir 6 dalam pengajaran mengenai cara-cara membaca al-Qur'an yang baik berkategori sedang; (c) pada butir 7 dalam pengajaran mengenai isi dan kandungan al-Qur'an berkategori sedang; ( $d$ ) pada butir 8 dalam pengajaran mengenai ilmu-ilmu fiqih berkategori sedang; (e) pada butir 9 dalam pengajaran mengenai cara-cara berperilaku atau berakhlak yang baik berkategori sedang; $(f)$ pada butir 10 dalam pengajaran mengenai kisah-kisah nabi dan rasul berkategori sedang; (g) pada butir 11 dalam pengajaran mengenai kisah nabi Muhammad SAW sebagai suri tauladan yang dapat ditiru dan diikuti dengan baik berkategori sedang; dan (b) pada butir 12 dalam pengajaran mengenai orang tua memberikan suri tauladan yang baik yang patut diikuti berkategori tinggi.

Pada poin a (pertanyaan butir 5) di atas, yang berkategori sedang mengindikasikan bahwa orang selalu memberikan pembelajaran kepada anaknya tentang pelajaran agama Islam secara umum, baik mengenai perilaku dalam kehidupan sehari-hari di antaranya cara bergaul yang baik, berbakti kepada kedua orang tua atau guru dan sebagainya, serta mengajarkan tentang hal-hal yang tidak boleh dilakukan (melanggar ajaran agama).

Pada poin $b$ (pertanyaan butir 6) dan poin $c$ (pertanyaan butir 7) masingmasing berkategori sedang mengindikasikan bahwa partisipasi orang tua terhadap 
belajar tentang al-Qur'an dan cara-cara membacanya mendapat perhatian yang serius karena dapat memberikan tambahan pengetahuan dengan mengajarkan di rumah selain yang diajarkan di musholla/masjid. Ini mengindikasikan bahwa orang tua meluangkan waktunya untuk mengajarkan dan mengevaluasi pemahaman anak-anaknya dalam membaca dan mempelajari isi kandungan alQur'an. Karena dengan mempelajari bacaan dan isi kandungan al-Qur'an nanti akan menjadikan siswa yang benar-benar memahami al-Qur'an.

Pada poin $d$ (pertanyaan butir 8) yang berkategori sedang mengindikasikan bahwa berpartisipasi orang tua untuk mengajarkan anak-anaknya yang berhubungan dengan ilmu-ilmu fiqih. Cakupan ilmu fiqih ini di antaranya mengenai cara-cara bersuci, bentuk-bentuk najis, mandi wajib, kewajiban sholat dan lain-lain, serta hal-hal yang sifatnya mendasar sehubungan dengan ilmu fiqih dalam kehidupan sehari-hari. Namun, partisipasi orang tua dalam pengajaran ilmu fiqih masih tergolong rendah.

Sehubungan dengan partisipasi orang tua dalam pembentukan akhlak/moral anaknya pada poin e (pertanyaan butir 9) berkategori sedang mengindikasikan bahwa pembelajaran akhlak dan cara-cara bergaul yang baik dianggap sangat penting dalam membina dan mendidik anak-anaknya. Dampak dari krisis moral dan etika bergaul yang baik ini mengakibatkan perilaku anakanak dikhawatirkan akan terjerumus ke arah pergaulan bebas, mengkonsumsi narkoba, minum minuman keras, dan lain-lain yang sejenisnya.

Sehubungan dengan partisipasi orang tua dalam menjelaskan tentang kisahkisah nabi dan rasul yang berjumlah 25 pada poin $f$ (pertanyaan butir 10) dan sejarah nabi Muhammad SAW pada poin $g$ (pertanyaan butir 11) berkategori sedang. Hal ini mengindikasikan bahwa dengan menceritakan kisah-kisah nabi dan rasul serta kisah nabi Muhammad SAW akan memberikan pemahaman kepada anak-anaknya bahwa setiap nabi dan rasul itu merupakan utusan/wakil Allah di muka bumi ini untuk memberikan pengajaran tentang ilmu-ilmu agama serta sejarah tentang orang-orang yang tidak senang kepada ajaran agama dan selalu memerangi nabi dan rasul Allah tersebut. sehingga dengan perjuangan para nabi dan rasul dan keteladanan rasul-rasul Allah tersebut dapat dijadikan sandaran untuk menjalankan ajaran agama dengan baik dan benar lebih-lebih kepribadian 
nabi Muhammad SAW yang memiliki sifat Al-Amin dapat dijadikan suri tauladan yang baik. Dengan sifat tersebut Nabi Muhammad SAW dapat menyebarkan agama Islam dengan baik karena sifat keramah tamahan, adil dan bijaksana, dan lain sebagainya. Sifat-sifat yang dimiliki oleh nabi Muhammad SAW ini dapat dijadikan pelajaran dan bahan acuan bagi anak-anak didik untuk menjadi anak pintar dan soleh/solehah berdasarkan tatanan ajaran Islam baik yang dipelajari di sekolah maupun atas bimbingan orang tua di rumah.

Sehubungan dengan peran orang tua dalam memberikan tauladan yang baik pada poin $h$ (pertanyaan butir 12) berkategori tinggi. Hal ini mengindikasikan bahwa kehidupan di lingkungan keluarga merupakan pembelajaran dan pembinaan mental anak yang pertama dan utama. Karena rumah adalah tempat berkumpulnya keluarga antara anak dan orang tua. Dalam rumah ini orang tua selalu memberikan pelajaran dan perilaku yang baik untuk di tiru dan diikuti oleh anak-anaknya. Jika anak dibesarkan dengan pendidikan yang baik maka anak akan bersemangat untuk belajar dan memacu untuk berprestasi. Begitu juga sebaliknya, jika diajarkan dengan perbuatan yang kurang baik maka anak akan berbuat lebih buruk dari apa yang telah orang tua lakukan. Oleh karenanya orang tua hendaknya memberikan tauladan yang baik yang dapat diikuti dan ditiru agar anak menjadi orang yang berguna bagi nusa, bangsa, dan agama.

Berdasarkan uraian di atas, secara keseluruhan partisipasi orang tua dalam memberikan motivasi berkategori sedang. Hal ini menggambarkan bahwa orang tua memiliki peran yang sangat penting dalam memotivasi, membangun kepribadian dan intelektualitas siswa untuk menyongsong masa depan anaknya yang lebih baik berdasarkan tuntutan agama Islam.

\section{c. Partisipasi dalam Memberikan Bimbingan}

Partisipasi orang tua dalam memberikan bimbingan kepada anak didiknya ini dapat digambarkan dari sebaran angket/kuesioner yang telah dijawab oleh siswa yang terpilih menjadi responden dan memberikan jawabannya yang terdiri dari beberapa butir pertanyaan sehubungan dengan pemberian bimbingan.

Di antara butir pertanyaan yang berkaitan dengan pemberian bimbingan yaitu; (1) memberikan nasihat jika anaknya berbuat salah berkategori tinggi; (2) 
pemberian sanksi jika berbuat yang kurang baik berkategori sedang; (3) memberikan semangat untuk meraih cita-cita/masa depan berkategori sedang; (4) mengarahkan untuk belajar ilmu agama berkategori sedang; (5) pemberian contoh tentang cara-cara yang baik dalam bergaul berkategori sedang; (6) pemberian contoh tentang cara-cara yang baik dalam berbicara atau berkata berkategori sedang; (7) dan membimbing dalam menjawab PR yang ditugaskan guru khususnya pelajaran agama Islam berkategori sedang.

Pada poin 1 berkategori tinggi, poin 2, dan 3 masing-masing berkategori sedang. Hal ini mengindikasikan bahwa bimbingan orang tua cukup signifikan dalam memberikan nasihat, pemberian sanksi jika berbuat salah, dan memberikan semangat untuk berprestasi. Pemberian nasihat disini tergolong tinggi, sedangkan pemberian semangat untuk berprestasi dan pemberian sanksi tergolong sedang. Pemberian sanksi jika berbuat salah ini merupakan salah satu bagian dari tuntunan yang diajarkan oleh Rasulullah SAW yang patut untuk diteladani oleh seluruh umat manusia pada umumnya dan umat Islam pada khususnya. Orang tua yang memahami tentang ilmu agama akan selalu memberikan pemahaman dan nasihat tentang sejarah orang-orang yang telah sukses meraih prestasi sehingga anak akan merasa tergugah untuk lebih disiplin, rajin dan semangat untuk belajar. Disisi lain orang tua juga dapat menceritakan kisah-kisah para sahabat, tabi'in, dan tabi'ittabi'in, serta para pejuang Islam yang telah mampu menemukan dan mengembangkan berbagai dimensi ilmu baik dalam ilmu-ilmu agama maupun dalam ilmu-ilmu umum yang dapat memberikan dampak positif dan dirasakan oleh seluruh masyarakat di dunia. Inilah hal-hal yang diceritakan kepada anaknya untuk menggapai cita-cita/masa depan yang penuh dengan kecanggihan (era modernisasi). Kesadaran orang tua akan pentingnya ilmu pengetahuan harus ditanamkan kepada anak-anaknya sehingga anak-anak kelak akan menjadi anak cerdas, jujur, adil, bermartabat, dan lain sebagainya. Hal inilah yang menjadi tujuan pendidikan yang berkarakter yang sedang digalakkan oleh pemerintah sekarang ini.

Pada poin 4, 5, dan 6 masing-masing berkategori sedang. Ini mengindikasikan bahwa orang tua selalu memberikan bimbingan dan tuntunan dalam belajar tentang ilmu-ilmu agama masih relatif sedikit. Sedangkan 
memberikan bimbingan dan tuntunan etika dalam bergaul baik dalam lingkungan keluarga maupun di lingkungan bermasyarakat, serta cara-cara dalam menyelesaikan segala persoalan dengan sikap dan tutur kata yang baik dan sopan santun tergolong tinggi. Belajar ilmu agama seperti yang dijelaskan di atas, merupakan suatu keharusan bagi setiap individu untuk menuntut.

Etika dalam bergaul merupakan suatu sikap yang patut untuk dimiliki oleh setiap manusia karena manusia sebagai makhluk sosial yang memiliki kepentingan dan kebutuhan terhadap orang lain. Sedangkan cara berbicara dan bertutur kata yang baik memiliki hubungan yang erat dengan etika bergaul. Jika orang tua dalam pergaulan dengan sikap yang baik dibarengi dengan tutur kata yang baik pula, maka akan memberikan pelajaran yang berharga bagi anak-anaknya. Karena anak dapat meniru perilaku dan sikap orang tua. Perilaku dan sikap orang seperti ini akan memiliki nilai positif bagi anak dalam melakukan interaksi baik dengan guru-gurunya maupun dengan teman-temannya dalam kehidupan sehari.

Pada poin 7 (membimbing dalam menjawab PR yang ditugaskan guru khususnya pelajaran agama Islam) berkategori sedang. Hal ini mengindikasikan bahwa orang tua selain sebagai guru dalam lingkungan keluarga juga memiliki tanggung jawab dalam mengevaluasi hasil belajar anak-anaknya. Dari hasil evaluasi tersebut maka orang tua dapat menentukan berbagai terobosan dan program untuk meningkatkan prestasi belajar anaknya. Orang tua juga dapat melihat keberhasilan anak-anaknya dalam belajar khususnya tentang agama Islam yakni melalui sikap, perilaku, tata krama, sopan santun, dan lain sebagainya sebagai hasil yang telah diperolehnya baik dari lingkungan keluarga, sekolah maupun di lingkungan masyarakat luas.

Berdasarkan uraian tentang partisipasi orang tua dalam membimbing anak didiknya di atas secara keseluruhan berkategori sedang. Hal ini menggambarkan bahwa dalam melakukan bimbingan kepada anak-anaknya, para orang tua memiliki waktu luang yang terbatas terutama sekali dalam bimbingan menjawab PR yang ditugaskan oleh gurunya. Namun bentuk partisipasi orang tua dalam membimbing yang cukup tampak di sini adalah memberikan nasihat, memberikan cara bergaul yang baik, bertutur kata yang baik, memberikan semangat dalam meraih cita-cita, memberikan sanksi jika bersalah. 


\section{d. Partisipasi dalam Memberikan Perhatian}

Partisipasi orang tua dalam memberikan perhatian kepada anak didiknya ini dapat digambarkan dari sebaran angket/kuesioner yang telah dijawab oleh siswa yang terpilih menjadi responden dan memberikan jawabannya yang terdiri dari beberapa butir pertanyaan sehubungan dengan pemberian perhatian.

Di antara butir pertanyaan yang berkaitan dengan pemberian perhatian yaitu; (1) perhatian orang tua mengenai kebutuhan-kebutuhan sekolah; (2) perhatian orang tua menceritakan tentang orang-orang yang sukses; (3) perhatian orang tua dalam berperilaku dan bergaul sesama temannya; (4) perhatian orang tua dalam pembelian buku-buku yang berkaitan dengan pelajaran di sekolah; (5) perhatian orang tua mencarikan guru dalam membimbing belajar; (6) perhatian orang tua dalam menanyakan pelajaran yang tidak dipahami di sekolah masingmasing berkategori sedang; (7) perhatian orang tua untuk datang ke sekolah menanyakan kepada guru tentang kesulitan belajar anaknya di sekolah berkategori rendah; (8) perhatian orang tua dalam menanyakan hasil ulangan/latihan; dan (9) perhatian orang tua menambah jam pelajaran di luar jam sekolah seperti mengikuti les/privat atau kursus masing-masing berkategori sedang.

Pada poin 1 dan 4 masing-masing berkategori sedang, mengindikasi bahwa bentuk kepedulian dan perhatian orang tua terhadap segala keperluan anak didiknya berkaitan dengan kebutuhan penunjang dalam menuntut ilmu di sekolah tergolong tinggi. Sedangkan perhatian orang tua dalam pembelian buku-buku yang berkaitan dengan pelajaran di sekolah tergolong sedang. Jika kebutuhan dan terpenuhi secara maksimal maka prestasi yang diharapkan pada anak didiknya dapat terwujud karena jenis kebutuhan ini merupakan kebutuhan yang paling utama.

Pada poin 2 berkategori sedang, merupakan bentuk perhatian yang mendorong anak didiknya untuk mendulang prestasi dengan menceritakan orangorang yang sukses. Persentase ini mengindikasikan bahwa dengan menceritakan orang-orang sukses dikarenakan ilmu pengetahuan yang dimilikinya diperoleh dengan rajin, tekun, tidak mudah menyerah, kreatif dalam belajar, disiplin, mandiri, bermartabat, berperilaku sopan, suka bergaul dengan teman, dan lain sebagainya. Disamping itu juga dapat menceritakan tentang sejarah tokoh-tokoh 
yang terkenal, pengusaha muda yang sukses, orang sukses dalam berkarya, dan lain sebagainya. Peristiwa-peristiwa atau kejadian seperti ini akan memberikan sugesti dan spirit yang besar dalam meraih prestasi yang gemilang.

Pada poin 3 berkategori sedang, mengindikasikan bahwa perhatian orang tua dalam pergaulan anaknya cukup signifikan. Mengindikasikan bahwa anak harus diperhatikan dan diawasi secara serius tentang pergaulan anaknya dengan teman-temannya. Jika anak bergaul dengan temannya dengan pergaulan yang baik maka sebagai orang tua seyogyanya lebih meningkatkan motivasi, spirit, suri taulan yang baik. Akan tetapi jika sebaliknya anak bergaul dengan temannya dengan pergaulan yang kurang baik maka sebagai orang tua memberikan sanksi, membimbing, menasihati dan jika diperlukan mendatangkan atau meminta bantuan kepada teman dekatnya untuk menasihatinya.

Pada poin 5 berkategori sedang. Poin 5 ini berkaitan terhadap perhatian orang tua dalam mencarikan guru dalam membimbing belajar belum optimal. Hal ini disebabkan karena para orang tua belum mengetahui dan memahami keunggulan bimbingan belajar dan belajar privat (mendatangkan guru ke rumah anak didik). Padahal program semacam ini sangat membantu siswa dalam menyelesaikan persoalan-persoalan yang berkaitan dengan materi pelajaran, lebihlebih persiapan dalam menghadapi UAS dan UN.

Pada poin 6 berkategori sedang. Sedangkan poin 7 berkategori rendah. Mengindikasikan bahwa perhatian orang tua dalam menanyakan pelajaran yang tidak dipahami di sekolah tergolong sedang dan perhatian orang tua untuk datang ke sekolah menanyakan kepada guru tentang kesulitan belajar anaknya di sekolah tergolong rendah. Melihat kondisi seperti ini, maka para orang tua belum secara optimal melakukan hubungan komunikasi dengan pihak penyelenggara sekolah sehingga para orang tua menganggap bahwa para dewan guru memiliki kemampuan dalam membimbing dan membina terhadap pendidikan anakanaknya. Disamping itu juga karena beban biaya pendidikan yang dibiayai oleh Negara menjadikan hubungan komunikasi antara pihak sekolah dan para orang tua merenggang jika dibandingkan dengan sistem pendidikan yang dibiayai oleh orang tua siswa sendiri. Karena melalui tagihan SPP kepada para orang tua siswa, dapat menjalin kerjasama untuk melakukan evaluasi dan pembinaan secara 
optimal karena para orang tua dapat melihat kinerja sekolah dalam memajukan pendidikan anak-anaknya.

Pada poin 8 dan 9 masing-masing berkategori sedang. Poin 8 dan 9 ini berkaitan dengan perhatian orang tua dalam menanyakan hasil ulangan/latihan dan perhatian orang tua untuk menambah jam pelajaran di luar jam sekolah seperti mengikuti les/privat atau kursus tergolong sedang. Hal ini mengindikasikan bahwa orang tua kurang peduli dalam mengontrol hasil ulangan dan latihan-latihan serta kurangnya melihat hasil PR yang diberikan oleh gurunya. Padahal, hasil ulangan tersebut sangat penting dalam melihat kemampuan, bakat, minat anak didiknya. Disamping itu perhatian orang tua untuk menambah jam pelajaran di luar jam sekolah seperti mengikuti les/privat atau kursus sangat antusias sekali, karena dengan adanya tambahan jam pelajaran di luar jam sekolah akan memberikan pengalaman berharga bagai anak untuk mengembangkan bakat dan minatnya. Karena pendidikan itu bukan saja di dalam lingkungan sekolah akan tetapi pendidikan juga banyak diketemukan di luar sekolah.

Berdasarkan uraian mengenai partisipasi orang tua memberikan perhatian secara keseluruhan berkategori sedang. Hal ini memberikan gambaran kepada para orang tua bahwa orang tua siswa sudah menyadari dan memiliki keinginan untuk memperhatikan segala kebutuhan yang menunjang pembelajaran pada anak didiknya baik di lingkungan keluarga maupun di lingkungan masyarakat luas.

Berdasarkan pembahasan mengenai partisipasi orang tua dalam memberikan motivasi, partisipasi orang tua dalam membimbing anak didiknya, dan partisipasi orang tua memberikan perhatian secara keseluruhan berkategori sedang. Dengan demikian dapat disimpulkan bahwa orang tua memiliki peran yang sangat penting dalam memotivasi, membangun kepribadian dan intelektualitas siswa untuk menyongsong masa depan anaknya yang lebih baik berdasarkan tuntutan agama Islam.

Sementara dalam melakukan bimbingan kepada anak-anaknya, para orang tua memiliki waktu luang yang terbatas terutama sekali dalam bimbingan menjawab PR yang ditugaskan gurunya. Namun bentuk partisipasi orang tua dalam membimbing yang cukup tampak di sini adalah memberikan nasihat, 
memberikan cara bergaul, bertutur kata yang baik, memberikan semangat dalam meraih cita-cita, memberikan sanksi jika bersalah.

Sedangkan mengenai partisipasi dalam orang tua dalam memberikan perhatian anak didiknya bahwa para orang tua siswa sudah menyadari dan memiliki keinginan untuk memperhatikan segala kebutuhan yang menunjang pembelajaran pada anak didiknya baik di lingkungan keluarga maupun di lingkungan masyarakat luas.

\section{KESIMPULAN}

Partisipasi orang tua terhadap pendidikan agama Islam anak didiknya tergolong sedang. Bentuk partisipasi orang tua ini terdiri atas pemberian motivasi, bimbingan, dan perhatian. Pemberian motivasi memiliki peran yang sangat penting dalam memotivasi, membangun kepribadian dan intelektualitas siswa untuk menyongsong masa depan anaknya yang lebih baik berdasarkan tuntutan agama Islam.

Pemberian bimbingan kepada anak didiknya yang paling nampak adalah memberikan nasihat, memberikan cara bergaul yang baik, bertutur kata yang baik, memberikan semangat dalam meraih cita-cita, memberikan sanksi jika bersalah. Sedangkan partisipasi dalam orang tua dalam memberikan perhatian anak didiknya untuk memperhatikan segala kebutuhan yang menunjang pembelajaran pada anak didiknya baik di lingkungan keluarga maupun di lingkungan masyarakat luas.

\section{DAFTAR PUSTAKA}

Arifin H.M. dan Aminuddin Rasyad, Dasar-dasar Pendidikan Edisi Revisi, Direktorat Jenderal Pembinaan Kelembagaan Agma Islam, 2003.

Arikunto, Suharsimi, Prosedur Penelitian Suatu Pendekatan Praktik. Jakarta : Rineka Cipta, 2010.

Dantes, Nyoman, Kerangka Dasar Penelitian Kuantitatif. Makalah : Disampaikan pada Seminar Metodologi Penelitian di Universitas Hindu Indonesia 29 Juli 2009. Singaraja : Universitas Pendidikan Ganesha, 2009.

Darajat Zakiyah., dkk, Ilmu Jiwa Agama, Edisi Revisi. Jakarta : Bulan Bintang, 2002.

Djamarah, Saiful Bahri, Pendidik dan Anak Didik Dalam Interaksi Edukatif Suatu Pendekatan Teoretis Psikologis. Jakarta : Rineka Cipta, 2010. 
Fauzil Adhim, "Agar Anak tak Krisis Identitas", Hidayatullah edisi 9/XIX Januari 2007. http://belajarpsikologi.com/Media-belajar-ilmu-psikologi-dan-bimbingan-konseling/ Posted by' Admin on December 31, 2009 diakses 15 Januari 2013

I. Wayan, AS. Standar Kompetensi (SK) dan Kompetensi Dasar (KD) Mata Pelajaran Pendidikan Agama Islam dan Bahasa Arab Madrasah Tsanawiyah, Jakarta: Azzahra, 2010

Margono, Metodologi Penelitian Pendidikan. Jakarta : Rineka Cipta, 2012.

Moleong, Leksi J. Metodologi Penelitian Kualitatif, Bandung : Remaja Rosda Karya, 2010.

Nasikhin M., dkk., 2005. Qur'an Hadits 3 Berdasarkan Kurikulum 2004 untuk Siswa Kelas IX Madrasah Tsanawiyah. Semarang: Aneka Ilmu.

Nasir, Moh. 2000, Metode Penelitian. Jakarta : Ghalia Indonesia.

Nasution. S., Metode Research (Penelitian Ilmiah), Jakarta : Bumi Aksara, 2012.

Sumarni, Meningkatkan Motivasi Belajar Matematika Melalui Metode Pemberian Kuis di Akhir Pembelajaran Disertai dengan Umpan Balike pada Siswa Kelas XI IP $A_{6} S M A$ Negeri 1 Sungguminasa Makasar, Skripsi. Makassar : Universitas Negeri Makassar Jurusan Matematika Fakultas matematika dan Ilmu Pengetahuan Alam, 2007.

Sugiyono, Metode penelitian kuantitatif kualitatif dan R\&D. Bandung: Alfabeta, 2008.

Syaodih S. N. 2005. Metode Penelitian Pendidikan. Bandung : Remaja Rosdakarya.

Sudjana, N. 2007. Media Pengajaran. Bandung : Sinar Baru.

Slameto, 2010. Belajar dan faktor-faktor yang Mempengarubinya. Jakarta : Rineka Cipta.

Umar Tirtaraharja dan S.L. La Sulo, Pengantar Pendidikan. Edisi Revisi. Jakarta : Rineka Cipta, 2005. 